\title{
Survei dan Pemetaan Untuk Perencanaan Jaringan Gas Bumi Bagi Rumah Tangga Menggunakan Metode Terrestrial dan Fotogrametri Jarak Dekat
}

\author{
Yanto Budisusanto, Khomsin, \& M. Nur Cahyadi \\ Jurusan Teknik Geomatika, FTSP, ITS \\ yanto_budisusanto@yahoo.com
}

\begin{abstract}
Abstrak
Upaya peningkatan pemanfaatan bahan bakar gas bumi untuk rumah tangga dan pelanggan kecil terhambat karena terbatasnya infrastruktur yang menghubungkan gas bumi dari sumbernya ke konsumen. Kegiatan survei dan pemetaan ini sangat diperlukan karena akan memberikan gambaran eksisting lokasi rencana jalur jaringan gas bumi. Dengan demikian kegiatan perencanaan akan lebih realistis, efektif dan efesien karena memperoleh informasi eksisting kondisi di lapangan sehingga dalam pelaksanaannya nanti tidak mengalami kendala yang berarti. Kegiatan survey dan pemetaan dalam rangka perencanaan jaringan gas rumah tangga ini dilakukan dengan dua metode yaitu, terrestrial dan fotogrammetri jarak dekat. Metode terrestrial digunakan untuk memberikan gambaran potongan memanjang dan melintang sepanjang jalur rencana pipa gas sedangkan fotogrammetri jarak dekat digunakan untuk memberikan gambaran tampak dari udara mengenai lokasi perencanaan jaringan pipa gas serta perkiraan sebaran pelayannya. Dari kegiatan ini diperoleh gambaran mengenai peta situasi, potongan memanjang dan melintang sepanjang jalur perencanaan pipa gas serta tampak sebaran layanan yang terjangkau. Peta-peta tersebut diharapkan dapat digunakan sebagai dasar perencanaan untuk jaringan pipa gas bagi rumah tangga terutama di lokasi yang dilakukan survey dan pemetaan.
\end{abstract}

Kata kunci: Survei, Pemetaan, Terrestrial, Fotogrametri

\section{PENDAhUluAN}

Upaya peningkatan pemanfaatan bahan bakar gas bumi untuk rumah tangga dan pelanggan kecil terhambat karena terbatasnya infrastruktur yang menghubungkan gas bumi dari sumbernya ke konsumen. Kurang berkembangnya infrastruktur gas bumi tersebut dikarenakan kendala perekonomian sehingga beberapa perusahaan belum tertarik mengembangkannya. Oleh karena itu perlu keterlibatan pemerintah untuk mempercepat penggunaan bahan bakar gas tersebut melalui "Pembangunan Jaringan Gas Bumi untuk Rumah Tangga".

Untuk mewujudkan pembangunan jaringan gas bumi untuk rumah tangga tersebut, diperlukan suatu perencanaan yang matang dan terprogram. Sebagai langkah awal maka perlu dilakukan survei dan pemetaan situasi di lokasi yang direncanakan akan dibangun jaringan gas bumi untuk rumah tangga. Kegiatan survei dan pemetaan ini sangat diperlukan karena akan memberikan gambaran eksisting lokasi rencana jalur jaringan gas bumi. Dengan demikian kegiatan perencanaan akan lebih realistis, efektif dan efesien karena memperoleh informasi eksisting kondisi di lapangan sehingga dalam pelaksanaannya nanti tidak mengalami kendala yang berarti.

Metode Terrestrial adalah dengan melakukan pengukuran dan pemetaan secara langsung ke lokasi untuk mengumpulkan data (data primer) tentang situasi pada koridor rencana jalur jaringan gas bumi. Dengan menggunakan metode ini diperoleh gambaran mengenai dimensi jalan baik lebar maupun panjang lintasan serta profil melintang dan memanjang. Adapun Metode fotogrametri jarak dekat digunakan sebagai informasi tambahan mengenai tampilan tampak atas lokasi survei dan pemetaan berupa citra resolusi tinggi. Citra tersebut memberikan kemudahan bagi pengguna untuk mengenali obyek di lapangan. Pengguna dapat memperoleh gambaran yang jelas (baca; membedakan obyek) mengenai persil bangunan, jalan dan penggunaan lahan di lokasi survey dan pemetaan. Dengan citra tersebut diperoleh data dijital persil bangunan beserta perkiraan jumlahnya.

Hasil dari kegiatan survey dan pemetaan ini adalah gambar detail jalan, profil melintang dan memanjang sepanjang koridor perencanaan jaringan gas bumi yang ditumpangtindihkan dengan citra resolusi tinggi sebagai informasi tambahan serta data dijital persil bangunan. 


\section{METODE PENELITIAN}

Untuk mengawali kegiatan survey dan pemetaan di wilayah perencanaan jaringan gas bumi untuk rumah tangga dengan melihat secara menyeluruh melalui google earth. Untuk kemudian ditindaklanjuti dengan meninjau secara langsung ke lapangansebagai langkah pengenalan lokasi kegiatan pemetaan. Pemasangan dan pengukuran titik kontrol horizontal menggunakan alat penentuan posisi teliti yaitu GPS adalah langkah berikutnya yang dilakukan. Titik-titik control horizontal tersebut digunakan sebagai titik control pemetaan situasi secara terrestrial menggunakan total station. Pemetaan situasi sepanjang koridor rencana jalur pipa jaringan gas bumi untuk menghasilkan peta detail jalan, profil melintang dan memanjang. Titik-titik control tersebut juga digunakan sebagai titik control tanah untuk koreksi geometri citra hasil fotogrametri jarak dekat menggunakan UAV. Sebagian lagi digunakan untuk titik control independen sebagai uji planimetris hasil koreksi geometric yang telah dilakukan. Uji planimertis menunjukkan kualitas geometri citra foto secara keseluruhan. Artinya jika telah memenuhi uji tersebut maka citra foto yang digunakan sudah dinyatakan layak dipergunakan secara geometri yaitu mengenai posisi dan bentuk obyek yang sama antara di citra foto dan lapangan.

Proses penggambaran detail situasi secara terrestrial menggunakan perangkat lunak pengolah gambar dilakukan setelah perhitungan data hasil pengukuran di lapangan dengan bantuan gambar sketsa dari surveyor pengukuran. Pengolahan citra foto menggunakan perangkat lunak pengolah foto udara dengan menggabungkan (mozaik) potongan-potongan foto yang saling bertampalan sehingga menghasilkan citra foto secara utuh lokasi survey dan pemetaan.

\section{HASIL DAN PEMBAHASAN}

Evaluasi melalui citra google earth memberikan gambaran lokasi yang akan dilakukan survey cukup padat pemukiman. Perlu strategi agar pelaksanaan dapat berjalan dengan lancer sedikit kendala. Terutama mengenai proses perijinan kepada pemerintah setempat yang berwenang. Gambar 1 adalah gambaran lokasi melalui citra google earth dan jalur-jalur yang akan dilakukan pemetaan situasi secara terrestrial.

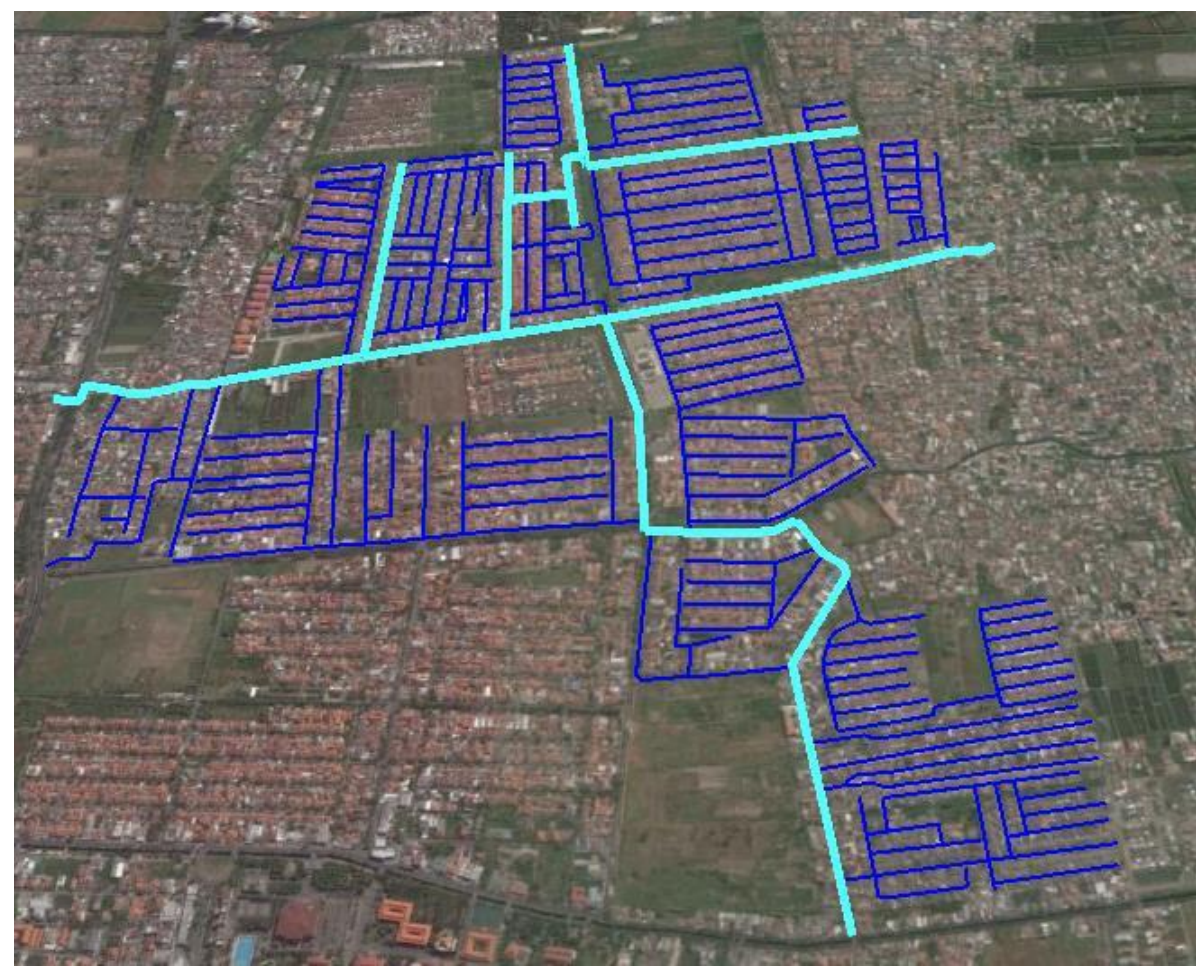

Gambar 1. Rencana Lokasi Survei dan Pemetaan Jaringan Gas Bumi Untuk Rumah Tangga

Untuk penyebaran titik-titik control baik untuk kegiatan survey dan pemetaan secara terrestrial dan sebagai titik control tanah untuk koreksi geometric citra foto resolusi tinggi serta titik control independen untuk uji planimetris dapat dilihat pada gambar 2 dan 3. Penempatan lokasi titik-titik control tersebut mempertimbangkan penyebarannya yang merata diseluruh lokasi survey. Titik-titik tersebut digunakan sebagai awal dan akhir dari kegiatan pemetaan situasi secara terrestrial. Titiktitik tersebut digunakan juga sebagai arah atau orientasi dari detail situasi pada saat pengolahan dan perhitungan data pengukuran lapangan. Untuk titik control yang digunakan sebagai titik control tanah dan titik control independen disamping mempertimbangkan hal tersebut diatas perlu juga memperhatikan bahwa lokasi titik yang dipilih mudah dan bisa dikenali obyeknya pada citra foto dan di lapangan. 


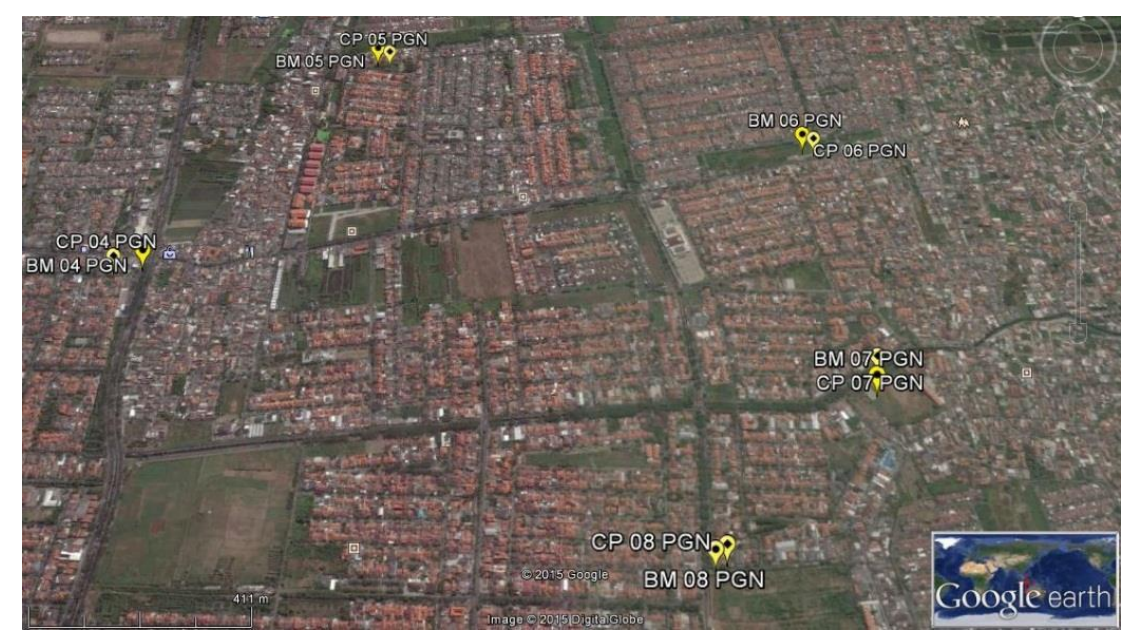

Gambar 2. Sebaran Titik-Titik Kontrol Dengan Kode BM dan CP

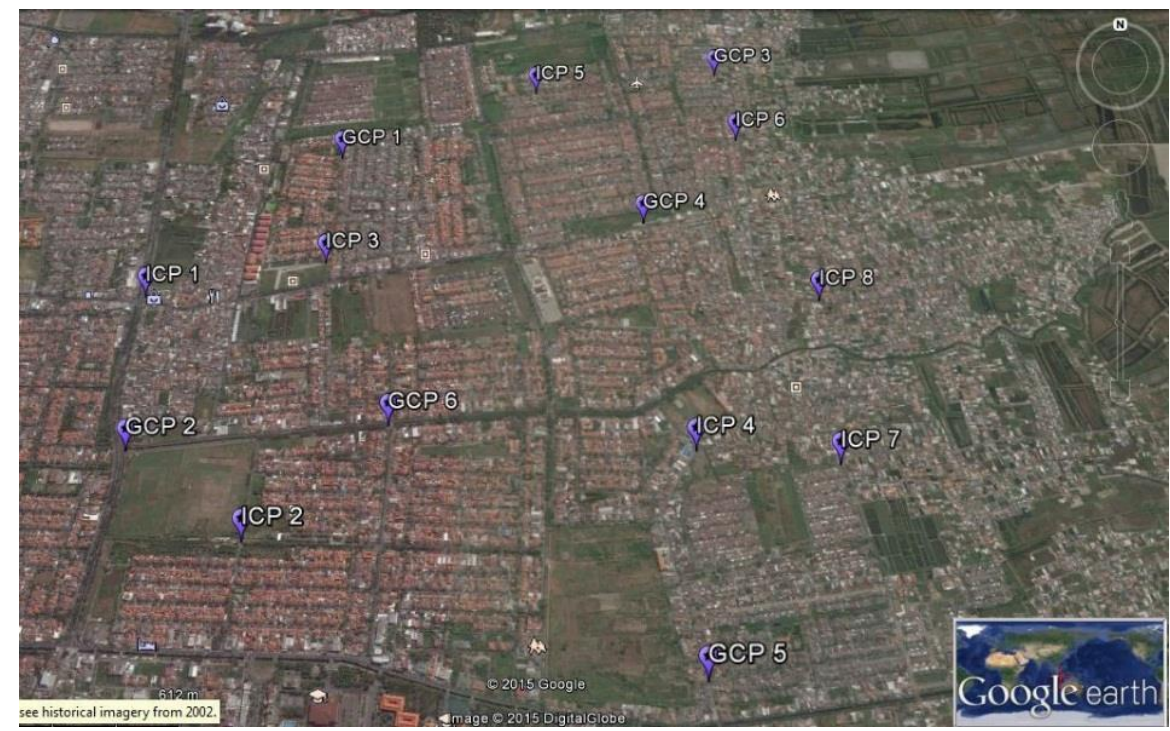

Gambar 3. Sebaran Titik-Titik Kontrol Tanah dan Titik-titik Kontrol Indenpenden

Tabel 1 dan 2 adalah hasil pengolahan dan perhitungan pengukuran titik-titik control yang ada di lapangan. Kode BM dan CP untuk titik control pemetaan situasi secara terrestrial dan kode GCP dan ICP titik yang digunakan untuk koreksi geometric dan uji planimetris citra foto jarak dekat menggunakan UAV. BM adalah . CP adaalah Control Point. GCP adalah Ground Control Point. ICP adalah Independent Control Point.

Tabel 1. Hasil Pengolahan Data GPS untuk Titik BM dan CP

\begin{tabular}{|c|c|c|c|c|c|c|}
\hline No & Name & Latitude & Longitude & Grid Northing $(\mathrm{m})$ & Grid Easting $(\mathrm{m})$ & Elevation $(\mathrm{m})$ \\
\hline 1 & BMO4 & $7^{\circ} 19^{\prime} 21.45868^{\prime \prime S}$ & $112^{\circ} 46^{\prime} 51.50454^{\prime \prime} \mathrm{E}$ & 9190195,997 & 696602,9861 & 3,354 \\
\hline 2 & CPO4 & $7^{\circ} 19^{\prime} 21.73606 " \mathrm{~S}$ & $112^{\circ} 46^{\prime} 49.40680^{\prime \prime} \mathrm{E}$ & 9190187,73 & 696538,607 & 2,961 \\
\hline 3 & $\mathrm{BMO5}$ & $7^{\circ} 19^{\prime} 00.99503 " \mathrm{~S}$ & $112^{\circ} 47^{\prime} 06.74364^{\prime \prime} \mathrm{E}$ & 9190822,833 & 697072,9232 & 2,92 \\
\hline 4 & CP05 & $7^{\circ} 19^{\prime} 01.14119 " \mathrm{~S}$ & $112^{\circ} 47^{\prime} 07.75725^{\prime \prime} \mathrm{E}$ & 9190818,219 & 697103,997 & 2,895 \\
\hline 5 & BM06 & $7^{\circ} 19^{\prime} 10.25521 " \mathrm{~S}$ & $112^{\circ} 47^{\prime} 41.36520^{\prime \prime} \mathrm{E}$ & 9190534,11 & 698133,7782 & 3,202 \\
\hline 6 & CP06 & $7^{\circ} 19^{\prime} 10.43032^{\prime \prime S}$ & $112^{\circ} 47^{\prime} 42.21812^{\prime \prime E}$ & 9190528,626 & 698159,9192 & 3,057 \\
\hline 7 & $\mathrm{BMO7}$ & $7^{\circ} 19^{\prime} 31.45588^{\prime \prime S}$ & $112^{\circ} 47^{\prime} 43.88794^{\prime \prime} \mathrm{E}$ & 9189882,464 & 698208,5587 & 2,23 \\
\hline 8 & $\mathrm{CP} 07$ & $7^{\circ} 19^{\prime} 29.83725^{\prime \prime S}$ & $112^{\circ} 47^{\prime} 44.16295^{\prime \prime E}$ & 9189932,158 & 698217,1928 & 2,403 \\
\hline 9 & CP08 & $7^{\circ} 19^{\prime} 43.09197 " \mathrm{~s}$ & $112^{\circ} 47^{\prime} 32.68524 " \mathrm{E}$ & 9189526,347 & 697863,5033 & 3,424 \\
\hline 10 & BM08 & $7^{\circ} 19^{\prime} 43.42758^{\prime \prime S}$ & $112^{\circ} 47^{\prime} 31.93975^{\prime \prime E}$ & 9189516,127 & 697840,5953 & 3,242 \\
\hline
\end{tabular}

Tabel 2. Titik-Titik Koordinat Kontrol Tanah dan Titik-titik Kontrol Independen 


\begin{tabular}{|l|r|r|r|}
\hline Name & Grid Northing $(\mathbf{m})$ & Grid Easting $(\mathbf{m})$ & Elevation $(\mathbf{m})$ \\
\hline ITSS1010a_KQ2O & 9194906,147 & 698128,862 & 19,444 \\
\hline GCP01_PANDUGO & 9190790,596 & 697168,227 & 2,747 \\
\hline ICP05_PANDUGO & 9191072,336 & 697795,422 & 2,686 \\
\hline GCP03_PANDUGO & 9191153,912 & 698402,811 & 2,687 \\
\hline ICP01_PANDUGO & 9190251,036 & 696628,503 & 2,744 \\
\hline ICP03_PANDUGO & 9190375,049 & 697154,036 & 2,894 \\
\hline GCP04_PANDUGO & 9190526,335 & 698129,792 & 3,12 \\
\hline ICP06_PANDUGO & 9190864,911 & 698448,791 & 2,727 \\
\hline GCP02_PANDUGO & 9189743,838 & 696662,995 & 3,436 \\
\hline GCP06_PANDUGO & 9189821,149 & 697381,401 & 3,277 \\
\hline ICP04_PANDUGO & 9189743,826 & 698235,152 & 2,756 \\
\hline ICP08_PANDUGO & 9190236,014 & 698639,879 & 2,955 \\
\hline ICP02_PANDUGO & 9189477,068 & 697016,262 & 3,011 \\
\hline GCP05_PANDUGO & 9189112,785 & 698218,721 & 2,47 \\
\hline ICP07_PANDUGO & 9189700,568 & 698628,94 & 2,767 \\
\hline
\end{tabular}

Gambar 4 dan 5 menggambarkan ketika pengukuran dilapangan. Pengukuran titik control menggunakan GPS dan detail situasi menggunakan alat ukur total station. Untuk titik control tanah dan titik control pemetaan situasi terbuat dari paralon cor ditanam ke tanah lebih kurang $30-40 \mathrm{~cm}$ dan muncul dipermukaan tanah 20 - $30 \mathrm{~cm}$. Diberi notasi kode titik control yaitu BM xx dan CP xx. Xx adalah no urut titik control. Untuk GCP dan ICP dipilih lokasi yang mudah dikenali di citra foto dan lapangan.

Pemetaan detail situasi dimaksudkan untuk memperoleh data-data situasi pada lokasi survey. Data-data tersebut adalah obyek-obyek yang ada dipermukaan tanah, seperti tiang listrik, tiang PJU, hydrant, saluran dan obyek lainnya yang dianggap diperlukan untuk memberikan gambaran secara utuh mengenai lokasi survei. Metode yang digunakan untuk mengukur detil situasi adalah metode tachymetri dengan menggunakan alat Total Station (lihat Gambar 6).

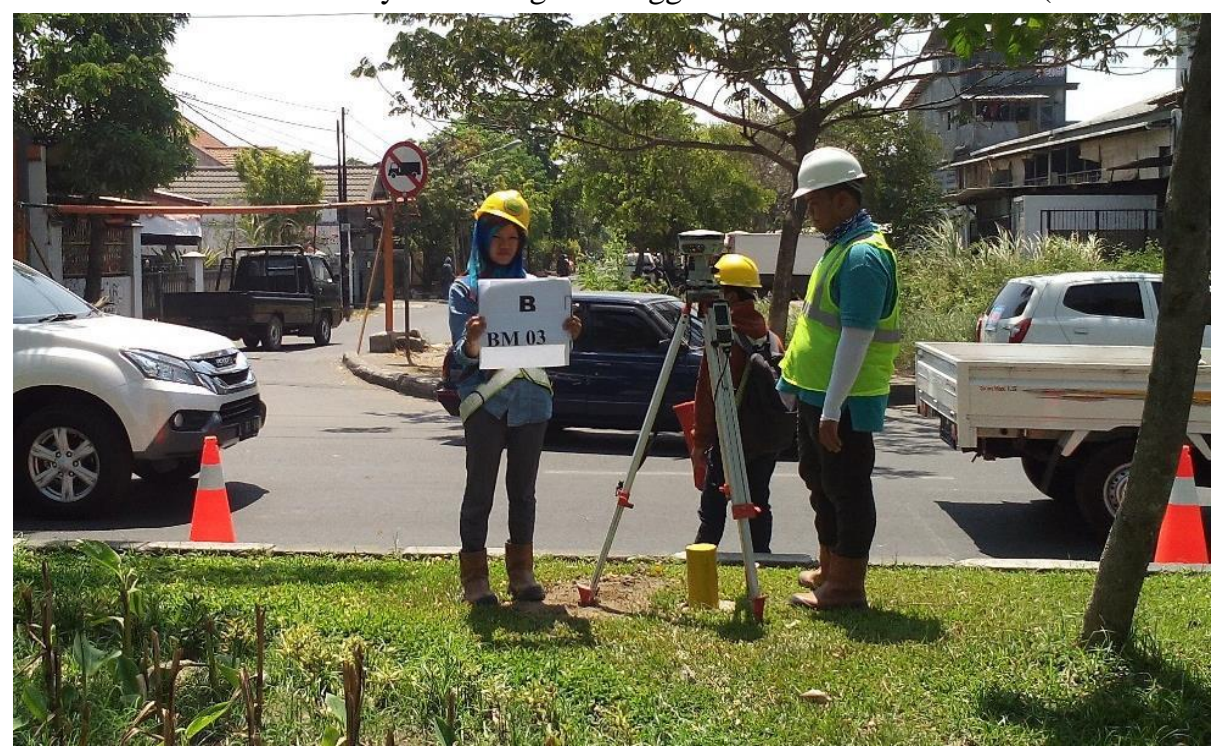

Gambar 4. Surveyor GPS melakukan Pengukuran Titik BM atau CP

Hasil pengolahan data pengukuran menggunakan alat ukur Total Station adalah berupa titik koordinat detail-detail obyek yang ada dipermukaan bumi direpresentasikan dengan titik, garis dan luasan. Adapun obyek-obyek yang dimaksud adalah detail jalan, tiang listrik, tiang telpon atau obyek lainnya yang dianggap sebagai obyek permanen dan perlu direpresentasikan dalam gambar peta situasi. Hasil perhitungan koordinat detail lapangan di gunakan sebagai data masukkan ke perangkat lunak pengolah gambar untuk kemudian dilakukan proses penggambaran. Dengan bantuan gambar sketsa lapangan obyek-obyek hasil pengukuran di lapangan diidentifikasi untuk kemudian dihubungkan sehingga merepresantasikan obyek yang ada di lapangan. Gambar 7 adalah hasil perhitungan, pengolahan dan penggambaran data pengukuran detail situasi di lapangan.

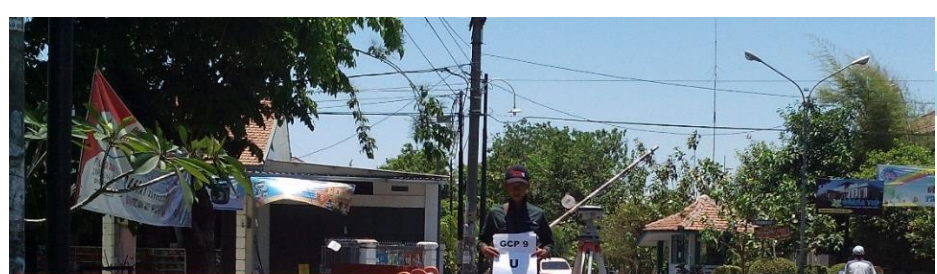



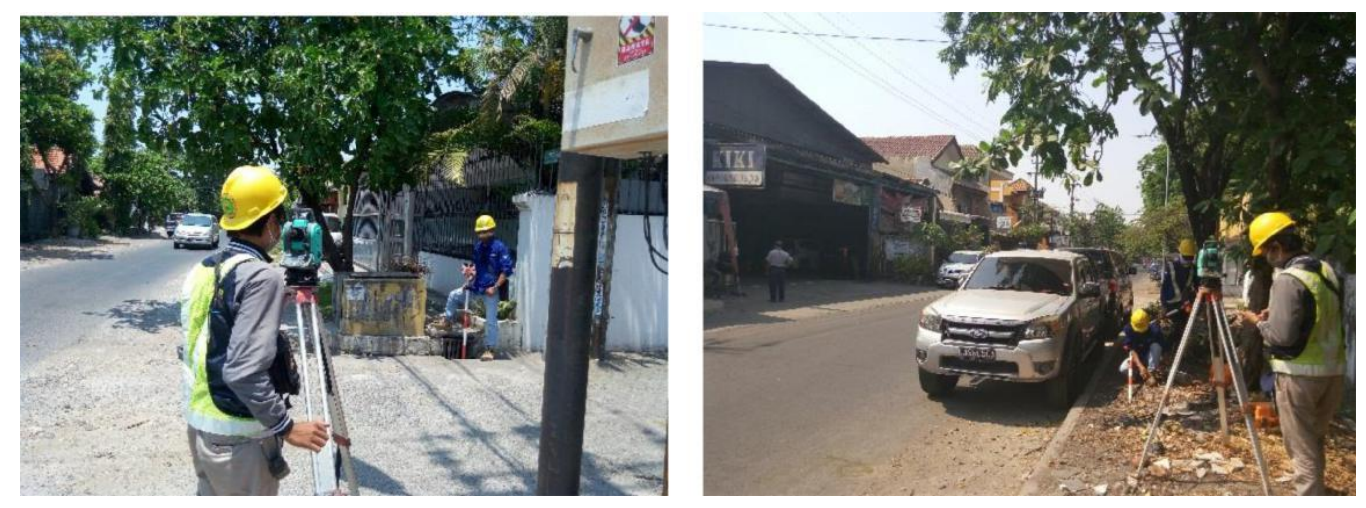

Gambar 6. Pemetaan Detail Situasi

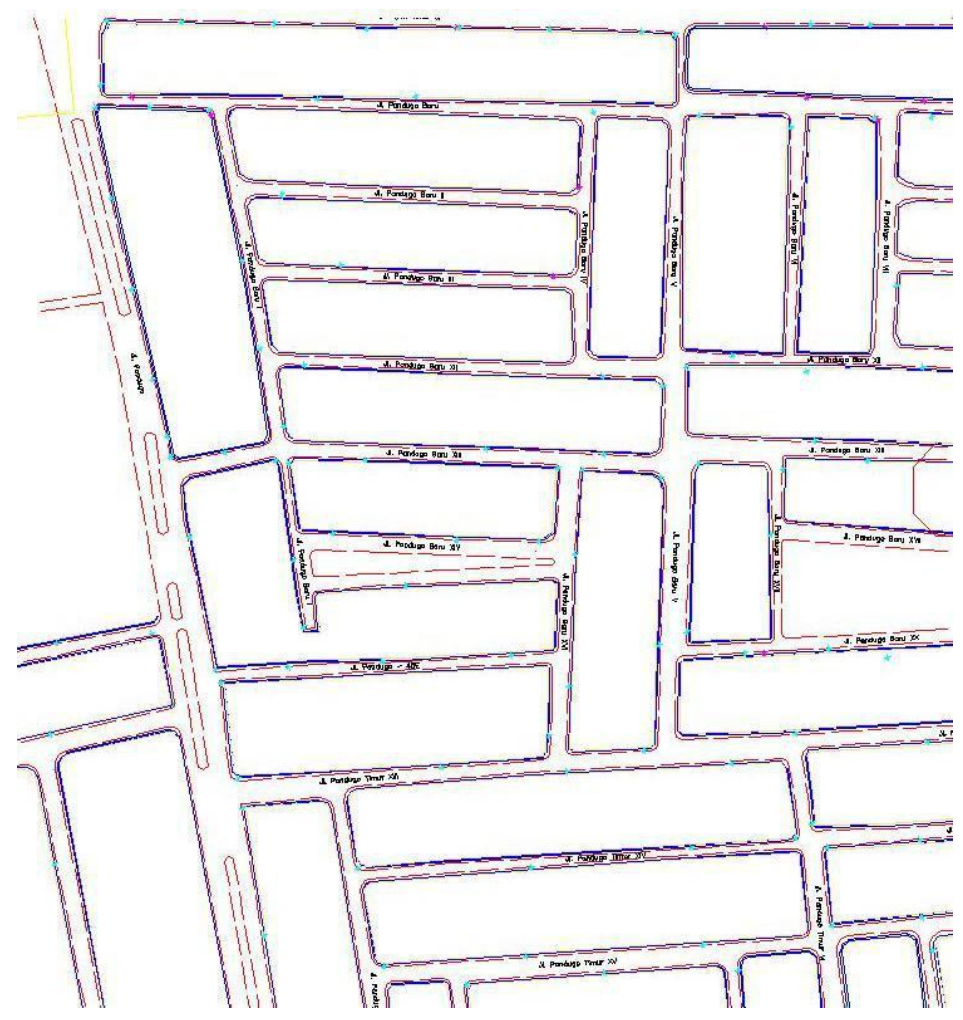

Gambar 7. Penggambaran Detail Pemetaan Situasi

Untuk lay out dalam bentuk lembar peta dapat dilihat pada Gambar 8. Gambar 8 adalah visualisasi pemetaan situasi berikut profil melintang dan memanjang pada lokasi yang dimaksud yang disebut dengan aligment sheet. Dari hasil penggambaran diperoleh lebih kurang 300 aligment sheet pada skala $1: 2500$. Lembar aligment sheet (lembar peta) ini yang akan ditindaklanjuti oleh perencana untuk menuangkan detail jaringan gas bumi untuk rumah tangga. Dengan bantuan lembar peta yang mencakup seluruh area perencanaan diharapkan dapat meminimalkan permasalahan dalam pelaksanaan pembangunan jaringan gas bumi di lapangan. Dengan perencanaan yang berdasar pada data lapangan akan lebih efektif dan efesien untuk memperkirakan segala kebutuhan yang akan muncul ketika pelaksanaan pemasangan jaringan gas bumi. Perencana memperoleh gambaran yang mendekati kondisi riil di lapangan. 


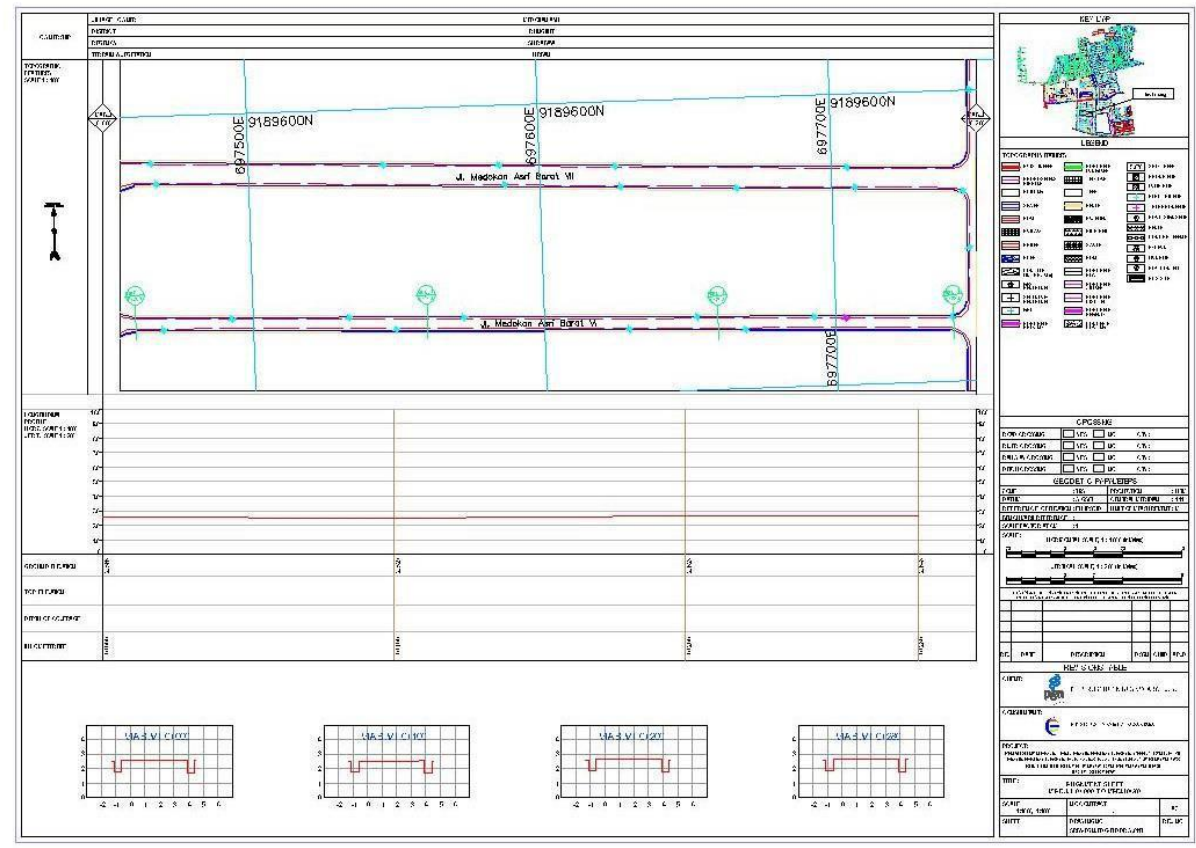

Gambar 8. Salah satu lembar peta aligment Shee

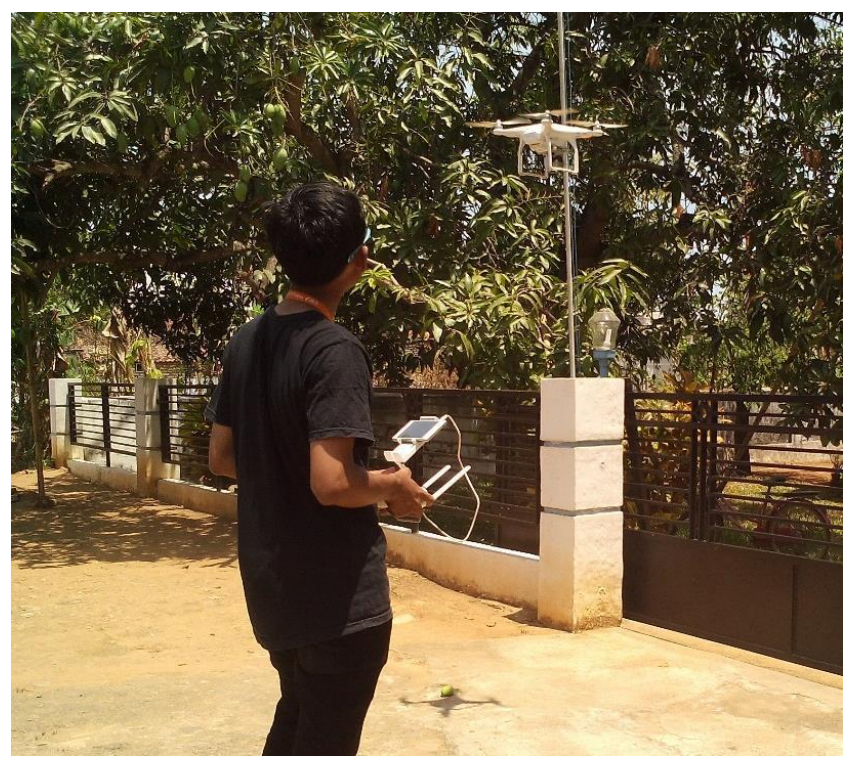

Gambar 9. Surveyor Pemotretan Udara Mengoperasikan wahan UAV

Gambar 9 adalah surveyor UAV mengoperasikan quadcopter yang dilengkapi dengan kamera dijital siap untuk memfoto lokasi dari udara. Lokasi untuk memulai penerbangan UAV dipilih area yang cukup lapang dan bisa melihat wahana secara luluasa dari darat.

Proses rektifikasi adalah proses memberikan sistem koordinat tanah pada citra sekaligus sebagai koreksi geometriknya. Pemberian sistem koordinat dalam sistem tertentu yang dalam hal ini sama dengan sistem koordinat hasil pengukuran GPS yaitu dalam sistem koordinat global UTM pada zona 49. Proses ini memanfaatkan titik-titik GCP dan sebagai uji planimetrisnya menggunakan titik-titik ICP. Gambar 10 adalah citra yang sudah terrektifikasi. Citra yang sudah direktifikasi secara geometri sama dengan di lapangan. Dengan citra ini perencana akan lebih mudah memperoleh gambaran lokasi yang akan dilakukan pengembangan jaringan gas bumi karena visualisasi obyek sama dengan kondisi di lapangan.

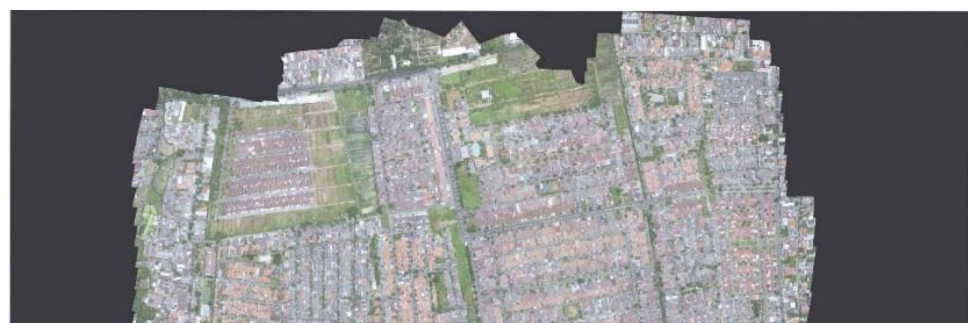


Gambar 10. Citra Terrektifikasi

Dijitasi citra/foto hasil rektifikasi adalah upaya mengkonversi data berformat raster menjadi vektor. Proses ini menggunakan perangkat lunak pengolah data gambar yang memiliki kemampuan untuk hal tersebut. Data vektor hasil dijitasi ini yang akan digunakan untuk proses selanjutnya yaitu untuk manipulasi dan perencanaan. Adapun obyek-obyek yang didijit adalah persil rumah, jalan dan obyek lainnya yang tampak dan dikenali melalui proses interpretasi secara visual. Gambar 11 adalah hasil dari proses dijitasi tersebut yang masih tertumpang tindih dengan data raster atau citra foto hasil survey menggunakan UAV. Sedangkan Gambar 12 adalah data vektor hasil proses dijitasi citra UAV. Dengan data vector yang sudah diperoleh bisa dilakukan preh persil bangunan yang bisa terlayani oleh jaringan gas bumi yang direncanakan.

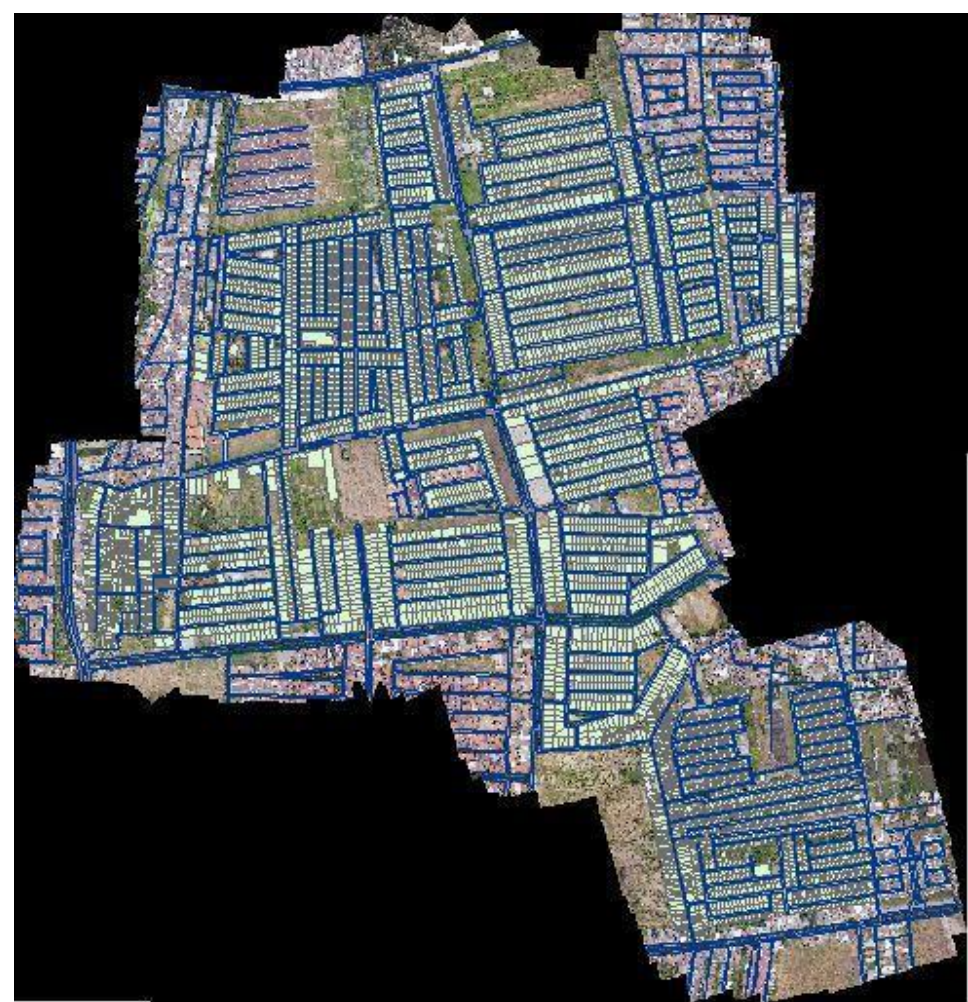

Gambar 11. Tumpangtindih Citra Foto dan Data Vektor Hasil Dijitasi Citra UAV

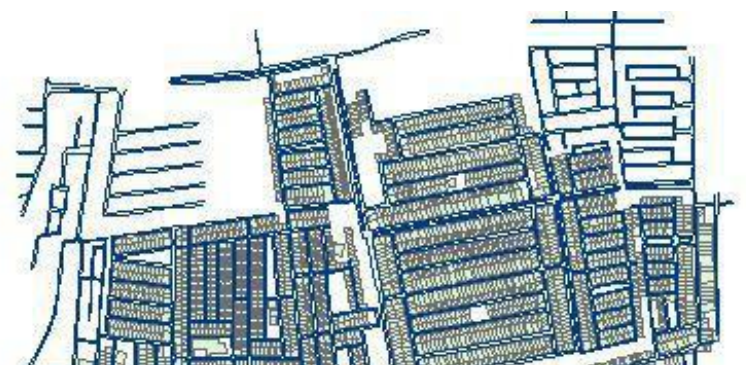




\section{Gambar 12. Data Vektor Hasil Dijitasi Citra UAV}

\section{KESIMPULAN}

Dari uraian diatas dapat ditarik beberapa kesimpulan adalah sebagai berikut :

1. Kegiatan survey dan pemetaan secara terrestrial menghasilkan peta detail situasi, profil memanjang dan melintang berkaitan dengan lokasi pengembangan jaringan gas bumi untuk rumah tangga.

2. Kegiatan survey dan pemetaan dengan menggunakan wahana tanpa awak (UAV) menghasilkan citra foto yang kemudian diolah menjadi data vektor untuk memprediksi jumlah persil bangunan yang dapat terlayani sepanjang jalur pengembangan jaringan gas bumi untuk rumah tangga.

3. Data peta detail situasi dan citra foto digunakan sebagai dasar untuk perencanaan pengembangan jaringan gas bumi untuk rumah tangga.

\section{Saran}

Dari hasil kegiatan yang telah dilakukan dapat diberikan saran adalah sebagai berikut :

1. Peta vector persil bangunan hasil dijitasi citra foto belum menggambarkan secara benar jumlah keluarga yang harus dilayani oleh jaringan gas bumi yang akan dikembangkan di lokasi tersebut. Oleh karena hal tersebut perlu dilakukan survey langsung berkaitan dengan data kependudukan yang dikaitkan dengan data vektor dari citra foto tersebut.

2. Penggabungan data vector dan atribut kependudukan akan lebih mudah dipahami jika dikembangkan dengan memanfaatkan teknologi Sistem Informasi Geografis bertema Jaringan gas bumi untuk rumah tangga.

\section{PUSTAKA}

Use the "Insert Citation" button to add citations to this document. 